Metallurgy and Foundry Engineering - Vol. 42, 2016, No. 1, pp. 69-78

http://dx.doi.org/10.7494/mafe.2016.42.1.69

Zofia Kwak, Aldona Garbacz-Klempka, Małgorzata Perek-Nowak, Łukasz Szymański

\title{
Correlation between mechanical properties of selected 7xxx series aluminum alloys obtained by semi-continuous casting
}

\author{
Zależności między właściwościami mechanicznymi \\ wybranych stopów aluminium serii 7xxx \\ otrzymanych na drodze półciągłego odlewania
}

\begin{abstract}
The studied ingots were made of alloys with a similar zirconium ratio, typically be given as: EN AW-7010 [AlZn6MgCu] and EN AW-7003 [Al Zn6Mg0,8Zr], in accordance with European standard PN-EN 573-3:2014-02 English version. The symbols $S$ and K are our internal modifications, compatible with the standard. The added zirconium was intended to improve the tensile strength resulting from plastic forming and an increasing resistance to cracking. Samples were taken from ingots made in the process of semi-continuous casting, some of which were homogenized; however, non-homogenized samples were also analyzed. The tests of tensile strength for the 7003, 7003S, and 7010K alloys were conducted longitudinally and transversely to the casting direction.The tensile strength test for 7010 was conducted only transversely to the direction of casting. The aim of this publication is to present the results of strength test sand to show a correlation between the basic properties of 7xxx-series aluminum alloys; i.e., relative elongation $E$, yield strength $Y S$, and ultimate tensile strength UTS.
\end{abstract}

Keywords: Al-Zn-Mg-Cu alloys, DC casting, quality of ingots, mechanical properties

\section{Streszczenie}

Ocenę wlewków prowadzono na stopach o zbliżonej zawartości cyrkonu, zazwyczaj podawanych jako EN AW-7010 [AIZn6MgCu] and EN AW-7003 [AlZn6Mg0,8Zr], zgodnie z europejską normą PN-EN 573-3:2014-02 - wersja angielska. Obecne w pracy oznaczenia K, S to modyfikacja

Zofia Kwak M.Sc. Eng., Aldona Garbacz-Klempka Ph.D. Eng.: AGH University of Science and Technology, Faculty of Foundry Engineering, Historical Layers Research Centre, Krakow, Poland; Małgorzata Perek-Nowak Ph.D. Eng.: AGH University of Science and Technology, Faculty of Non-Ferrous Metals, Krakow, Poland; Łukasz Szymański M.Sc. Eng.: AGH University of Science and Technology, Faculty of Foundry Engineering, Krakow, Poland; kwakzosia@gmail.com 
wewnętrzna zgodna z normą. Wprowadzony cyrkon ma za zadanie poprawę właściwości wytrzymałościowych stopów otrzymanych na drodze przeróbki plastycznej oraz zwiększenie ich odporności na pękanie. Próbki zostały pobrane z wlewków otrzymanych na drodze odlewania półciągłego, w stanie niehomogenizowanym i homogenizowanym. Badania wytrzymałości na rozciąganie przeprowadzano w kierunku podłużnym i poprzecznym w odniesieniu do kierunku odlewania stopów 7003, $7003 \mathrm{~S}$ i 7010K. Dla stopu 7010 wytrzymałość na rozciąganie badano w próbie poprzecznej do kierunku odlewania. Celem publikacji jest prezentacja wyników badań właściwości wytrzymałościowych. Praca ma również na celu pokazanie korelacji pomiędzy podstawowymi właściwościami, tj. wydłużeniem względnym $A$, umowną granicą plastyczności $R_{\mathrm{p} 0,2}$ a wytrzymałością na rozciąganie $R_{m}$.

Słowa kluczowe: stopy Al-Zn-Mg-Cu, odlewanie półciągłe, jakość wlewków, właściwości mechaniczne

\section{Introduction}

The advantages of Al-Zn-Mg-Cu alloys are undoubtedly their good strength, light weight, and resistance to corrosion. The strength of 7xxx-series aluminum alloys increases with an increased concentration of Zn. Therefore, these alloys are widely used in the aviation industry [1] .

Rising client expectations in regards to the quality of products require the development of new technologies that improve the quality of casting. The control of the refining and modification processes enables us to keep the mechanical properties of the product on the desired high level. This can be also provided by precipitation hardening carried out by the appropriate heat treatment (three basic steps: solution treatment, quenching, and aging). Due to these development trends, a constant development of aluminum alloys can be observedin the latest data. This development makes it possible to design newer, more durable, and lighter construction. The role of micro-additions is crucial in this matter because they enables to set the alloy properties at the appropriate levels, making them highly durable. This is why they are possessed so much attention nowadays. Micro-additions significantly influence the kinetics of phase transitions, macro-, and micro-structure this way, forming final results that can be observed in material strength properties [2-4].

Aluminum alloys of the 7003 series are mainly used in the automotive industry. They are characterized by perfect energy absorption and good plasticity. These qualities are needed in this application area and provide a good solution. Aluminum alloys of the 7010 series are mainly used in the aviation industry due to their fatigue resistance and resistance to corrosion. This European alloy has properties similar to its American counter part of the 7050 series and is mainly used in the aviation industry as well. Usage of this material in the production of highly durable parts offers a balance between mechanical propertiesand resistance to stress corrosion. Despite this, it is not suitable for application at elevated temperatures. The most-common applications of the 7010 alloy are durable aviation parts, closed die forgings for the aviation industry, and large forged bars for the aviation industry [5-8]. 
The high quality of an $\mathrm{Al}-\mathrm{Zn}-\mathrm{Mg}-\mathrm{Cu}$ ingot impacts the functional properties of the final products obtained during plastic working. A key aspect of the casting process is the speed of the casting process; i.e., velocity of supplying metal to chill mould. This stage is also influenced by cooling and lubrication.

\section{Process description of direct chill casting}

On the following pages, a typical vertical direct chill casting installation is presented (Fig. 1). Using individual flow control or by a flooded table, the metal can be distributed by launders separately to each mold. In this technology, the metal flows through a refractory pan mounted on top while the molds are placed in a common water jacket. The proper temperature of metal is obtained using multiple furnaces in which the alloy is kept until the beginning of the casting process.

The flow of metal along the launder begins either when the furnace tilts or the drains or plug holes are opened. The necessary water in the cooling process during casting is delivered by a system with the molds being fed from a header tank. Water slots or holes are used to spray the water onto the ingot. Most of the time, the liquid pool depth is 0.7 times greater than the ingot's radius, but this depends mainly on the casting speed, type of alloy used, and size of ingot. The processed water goes back into the circuit. Compared to continuous casting, the molds are short and the casting speed is low [9].

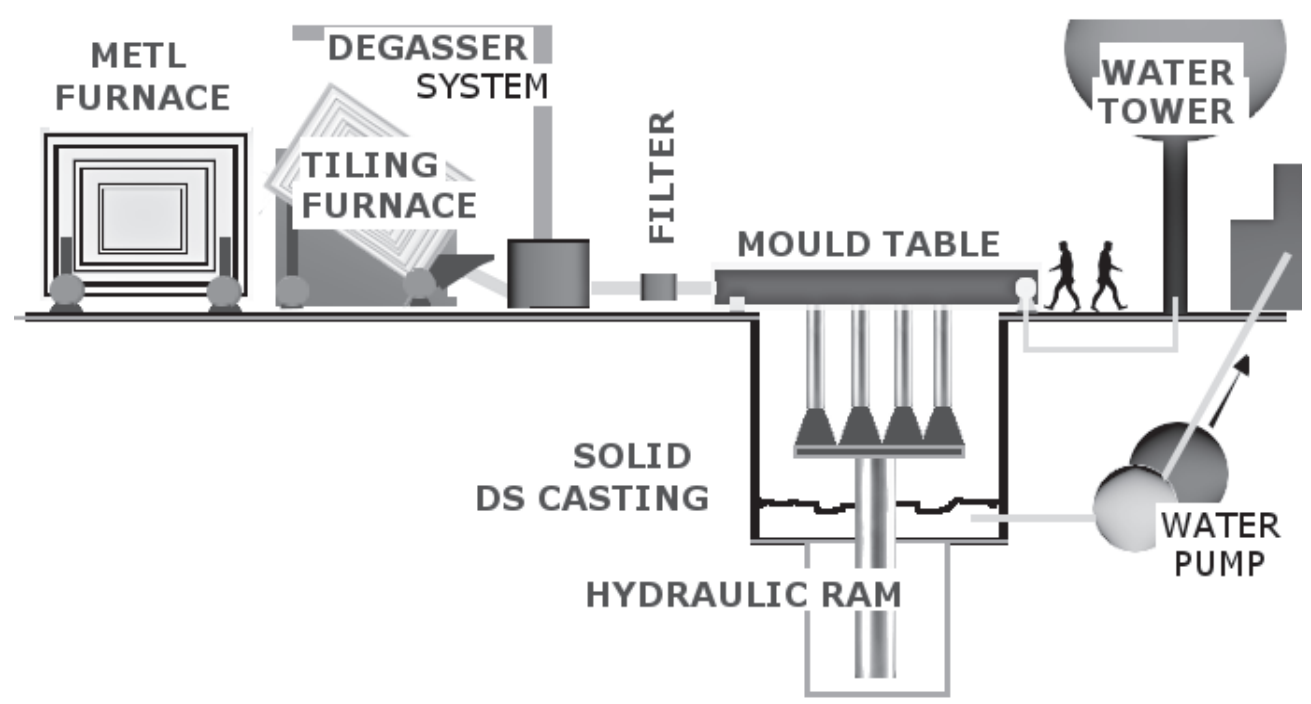

Fig. 1. A typical vertical direct chill casting installation [based on 10] 


\section{The research methodology}

Two alloys with similar zirconium content were analyzed. The chemical composition of samples made of 7003 and 7010 ingots was evaluated at flame spectrophotometer ARL 3460 OES. The results are represented in Tables 1 and 2.

Table 1. Chemical composition of aluminum alloy EN AW-7003 (AlZn6Mg0.8Zr) [10]

\begin{tabular}{|c|c|c|c|c|c|c|c|c|c|c|c|}
\hline \multirow{2}{*}{ Origin } & \multicolumn{10}{|c|}{ Chemical composition [\%wt.], remainder Al } \\
\cline { 2 - 13 } & $\mathbf{S i}$ & $\mathbf{C u}$ & $\mathbf{M g}$ & $\mathbf{M n}$ & $\mathbf{F e}$ & $\mathbf{Z n}$ & $\mathbf{T i}$ & $\mathbf{~ N i}$ & $\mathbf{Z r}$ & $\mathbf{C r}$ & $\mathbf{V}$ \\
\hline PN-EN 573-3 & $\leq 0,3$ & $\leq 0,2$ & $0,5-1,0$ & $\leq 0,3$ & $\leq 0,35$ & $5,0-6,5$ & $\leq 0,2$ & - & $0,05-0,25$ & $\leq 2,0$ & - \\
\hline $\begin{array}{c}\text { spectral } \\
\text { analysis }\end{array}$ & 0,05 & 0,05 & 0,89 & 0,16 & 0,22 & 5,89 & 0,03 & 0,01 & 0,15 & 0,01 & 0,01 \\
\hline
\end{tabular}

Table 2. Chemical composition of aluminum alloy EN AW-7010 (AlZn6MgCu) [10]

\begin{tabular}{|c|c|c|c|c|c|c|c|c|c|c|c|c|}
\hline \multirow{2}{*}{ Origin } & \multicolumn{10}{|c|}{ Chemical composition [\%wt.], remainder Al } \\
\cline { 2 - 13 } & $\mathbf{C}$ & $\mathbf{C u}$ & $\mathbf{M g}$ & $\mathbf{M n}$ & $\mathbf{F e}$ & $\mathbf{Z n}$ & $\mathbf{T i}$ & $\mathbf{N i}$ & $\mathbf{Z r}$ & $\mathbf{C r}$ & $\mathbf{V}$ & $\mathbf{G a}$ \\
\hline PN-EN 573-3 & $\leq 0,12$ & $1,5-2,0$ & $2,1-2,6$ & $\leq 0,10$ & $\leq 0,15$ & $5,7-6,7$ & $\leq 0,06$ & $\leq 0,05$ & $0,10-0,16$ & $\leq 0,05$ & - & - \\
\hline $\begin{array}{c}\text { spectral } \\
\text { analysis }\end{array}$ & 0,08 & 1,72 & 2,36 & 0,07 & 0,14 & 5,92 & 0,04 & 0,01 & 0,14 & 0,00 & 0,11 & 0,01 \\
\hline
\end{tabular}

For the 7003, 7003S, and 7010K alloys, tensile strength tests were conducted in directions perpendicular and parallel to the casting direction. The selection and preparation of the samples are presented in Figures 2-4. In the case of the 7010 alloy, the tests were conducted only in the direction parallel to casting. The samples of 7003, 7003S, and $7010 \mathrm{~K}$ alloys were rectangular, while those of the 7010 alloy were round. The samples were prepared according to PN-EN 10002-1 + AC1. The samples were deformed by a Zwick/Roell Z3000 tensile machine. The presented results are mean values of the number of parallel measurements taken.

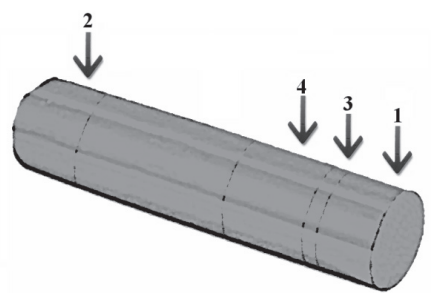

Fig. 2. Diagram of sample selection: 1 - ingot head; 2 - ingot base; 3 - slice for the chemical analysis, hardness test, and microstructure analysis; 4 -slice meant for the study of tensile strength in the direction perpendicular and along the ingots' length and for the analysis of the macro-structure 


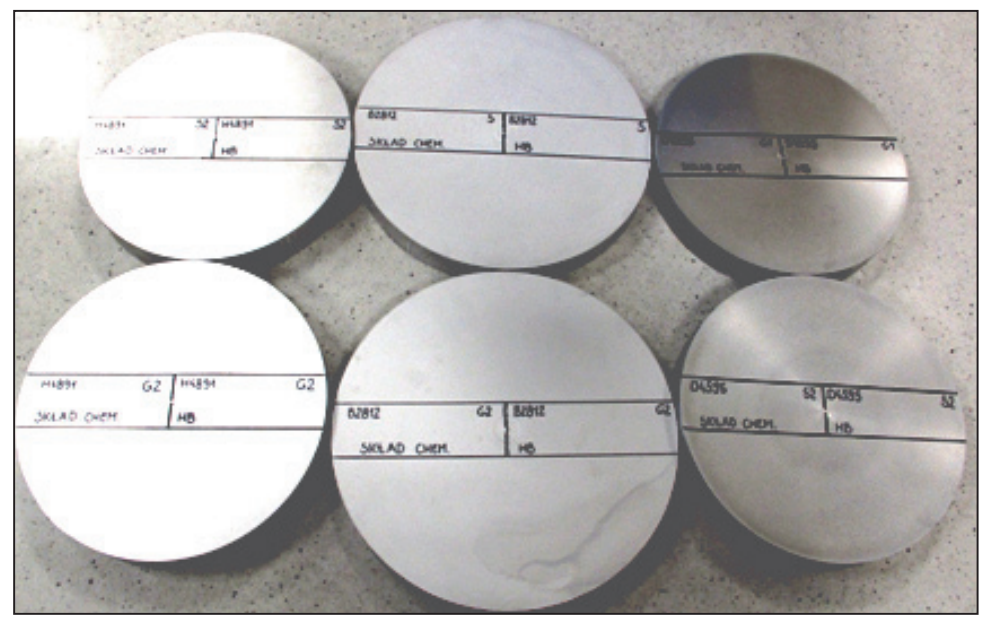

Fig. 3. Slices prepared for chemical analysis and hardness tests

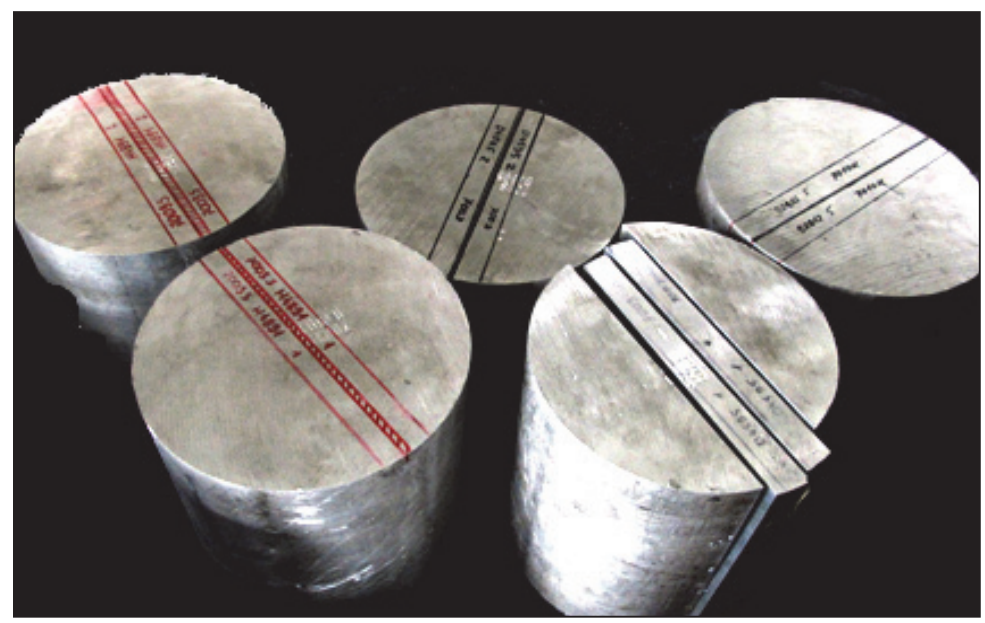

Fig. 4. Samples cut for tensile strength tests

Hardness tests for all alloys have been conducted on samples from slices cut perpendicularly to the direction of casting (Fig. 3). The hardness measurement for samples of the 7003, 7003S, and 7010K alloys was conducted by a ZWICK hardness tester equipped with test Xpert V 12.3 Master software. The hardness for samples of the 7010 alloy were measured by a universal Brinell hardness tester.

All measurements were taken at a temperature of $20^{\circ} \mathrm{C}$.

As a form of summary of the gathered results, a correlation between basic material properties has been presented - that is, between relative elongation $E$ [\%], yield strength YS [MPa], and ultimate tensile strength UTS [MPa]. 


\section{Results and discussion}

\subsection{Mechanical properties}

Hardness $\mathrm{HB}$, yield strength, and elongation of the alloys (before and after homogenization) are indicated in Table 3. Alloy 7010 was homogenized at $440^{\circ} \mathrm{C}$ for $24 \mathrm{~h}$.

Table 3. Comparison of the mechanical properties for alloys 7003, 7003S, 7010K, and 7010 homogenized $\left(T=440^{\circ} \mathrm{C}, \tau=24 \mathrm{~h}\right)$ and non-homogenized

\begin{tabular}{|c|c|c|c|c|}
\hline Type of alloy & UTS [MPa] & YS [MPa] & $\boldsymbol{E}[\%]$ & HB \\
\hline 70035 & 295 & 176 & 6,42 & 98 \\
\hline 7003 & 320 & 190 & 9,25 & 96 \\
\hline $7010 \mathrm{~K}$ & 269 & 134 & 8,38 & 80 \\
\hline $\begin{array}{c}7010 \\
\text { non-homogenized }\end{array}$ & 244 & - & 0,47 & 127 \\
\hline $\begin{array}{c}7010 \\
\text { homogenized }\end{array}$ & 194 & 99 & 3,95 & 75 \\
\hline
\end{tabular}

From the analysis of the hardness test results, we can see that the 7010 alloy that was not homogenized has the highest Brinell hardness. Values that follow are $98 \mathrm{HB}$ and $96 \mathrm{HB}$ for alloys $7003 \mathrm{~S}$ and 7003, respectively. In the case of the 7003S alloy, values slightly higher than mean hardness have been noted in the distance of a few millimeters from the middle of the ingot. The lowest hardness was found for the 7010 alloy that was being homogenized at $440^{\circ} \mathrm{C}$ for 24 hours.

Tensile strength tests for 7003, 7003S, and 7010K alloys have been conducted perpendicularly and along the direction of the casting. For the 7010 alloy, the tests were only conducted perpendicularly to the casting direction. There are differences in the tests results because of this; therefore, comparing them is difficult.

Tensile strength for the chosen materials was similar both in the directions along the ingots' length and across it. In alloys $7003 \mathrm{~S}$ and $7010 \mathrm{~K}$, higher values of tensile strength were observed on the ingots edge in the test perpendicular to the casting direction, while in the test along the ingots' length, higher values can be observed in the middle. Next was alloy $7003 \mathrm{~S}$ with a mean tensile strength of $295 \mathrm{MPa}$. The $7010 \mathrm{~K}$ and 7010 non-homogenized alloys had a similar UTS as the 70035 alloy. The homogenized 7010 alloy had the lowest tensile strength.

Yield strength for boththe 7003 and 70035 alloys was $190 \mathrm{MPa}$. Much lower values were measured for the $7010 \mathrm{~K}$ and 7010 after homogenized ingots.

An elongation $E$ of $9.2 \%$ was measured for the 7003 alloy. A similar value of $8.35 \%$ was measured for alloy $7010 \mathrm{~K}$. For $7003 \mathrm{~S}$, elongation reached $6.42 \%$, and 7010 homogenized $-3.95 \%$. 
In previous studies the following phases have been detected for 7003 alloy: $\mathrm{Al}_{4} \mathrm{Cu}_{2} \mathrm{Mg}_{8} \mathrm{Si}_{7}, \mathrm{AlCuMg}, \mathrm{Al}_{2} \mathrm{O}_{3}$. For $7003 \mathrm{~S}$ and $7010 \mathrm{~K}$ alloys the phases were: $\mathrm{Al}_{4} \mathrm{Cu}_{2} \mathrm{Mg}_{8} \mathrm{Si}_{7}$, AlCuMg, $\mathrm{Al}_{2} \mathrm{O}_{3}$ and $\mathrm{Al}_{2} \mathrm{Cu}$ [11]. Resemblance can be seen in materials macro- and microstructure and explain by similar strength tests results.

\subsection{Correlation between selected mechanical properties of the 7xxx alloy series}

Statistical analysis of correlation between elongation and UTS were performed using data recorded during tensile tests of $7 x x x$ alloys subjected to the research program.

Under analysis were the statistical correlations between the selected mechanical properties of $7 x x x$ series aluminum alloys, with a particular emphasis on the linear correlation between elongation $E$ [\%] and ultimate tensile strength UTS [MPa] (Figs 5-7). Characteristics relating yield strength to ultimate tensile strength (Fig. 8) are also drawn.

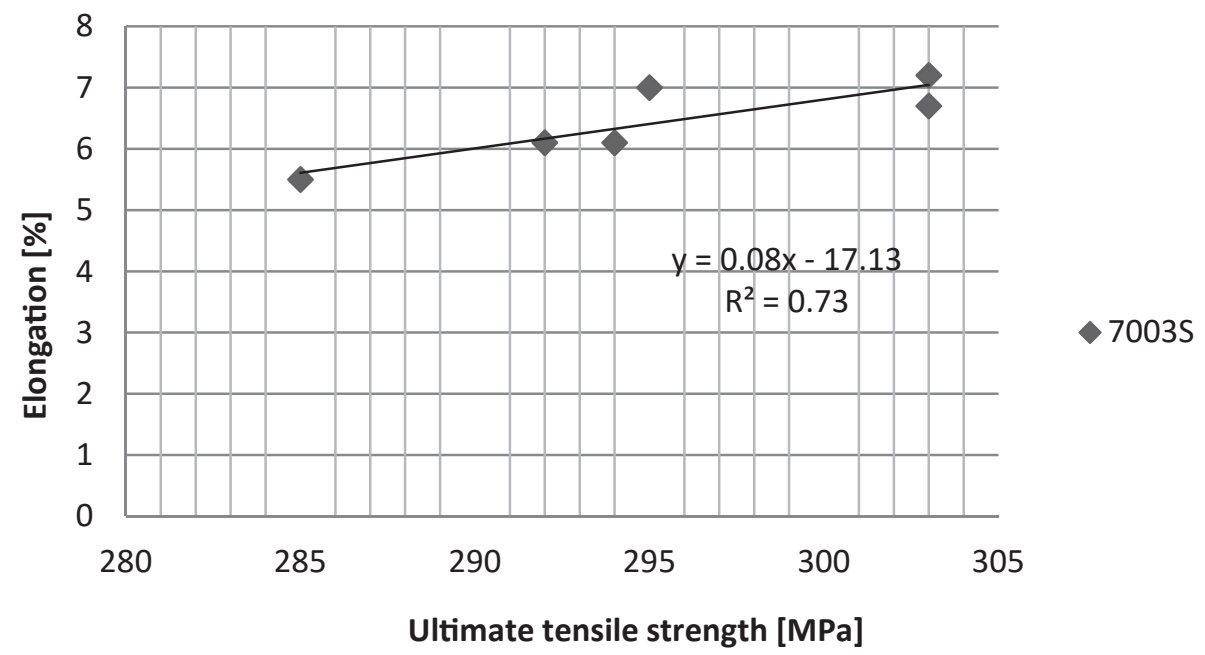

Fig. 5. Linear correlation between elongation and ultimate tensile strength of the sample made of the 70035 alloy

There is a clear linear dependence between elongation $E$ and ultimate tensile strength UTS, for all 7010K, 7003, and 7003S alloys (Figs 5-7). The correlation coefficients are $R^{2}=0.93, R^{2}=0.85$, and $R^{2}=0.73$ for $7010 \mathrm{~K}, 7003$, and 7003S, respectively.

No linear correlation $\left(R^{2}=0.44\right)$ can be observed between the yield strength and ultimate tensile strength for the $7003 \mathrm{~S}$ alloy (Fig. 8). For alloys 7003 and $7010 \mathrm{~K}$, there is 
no linear dependency between these values (for 7003 , correlation is $R^{2}=0.08$, and for $7010 \mathrm{~K}-R^{2}=0.16$ ).

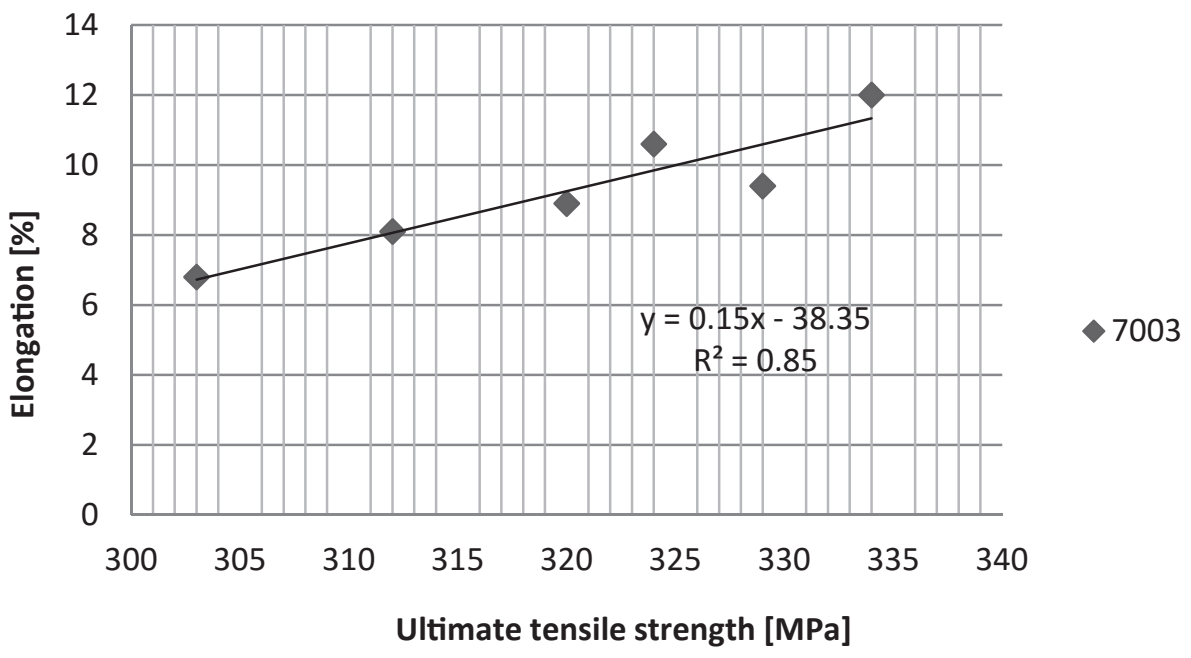

Fig. 6. Linear correlation between elongation and ultimate tensile strength of the sample made of the 7003 alloy

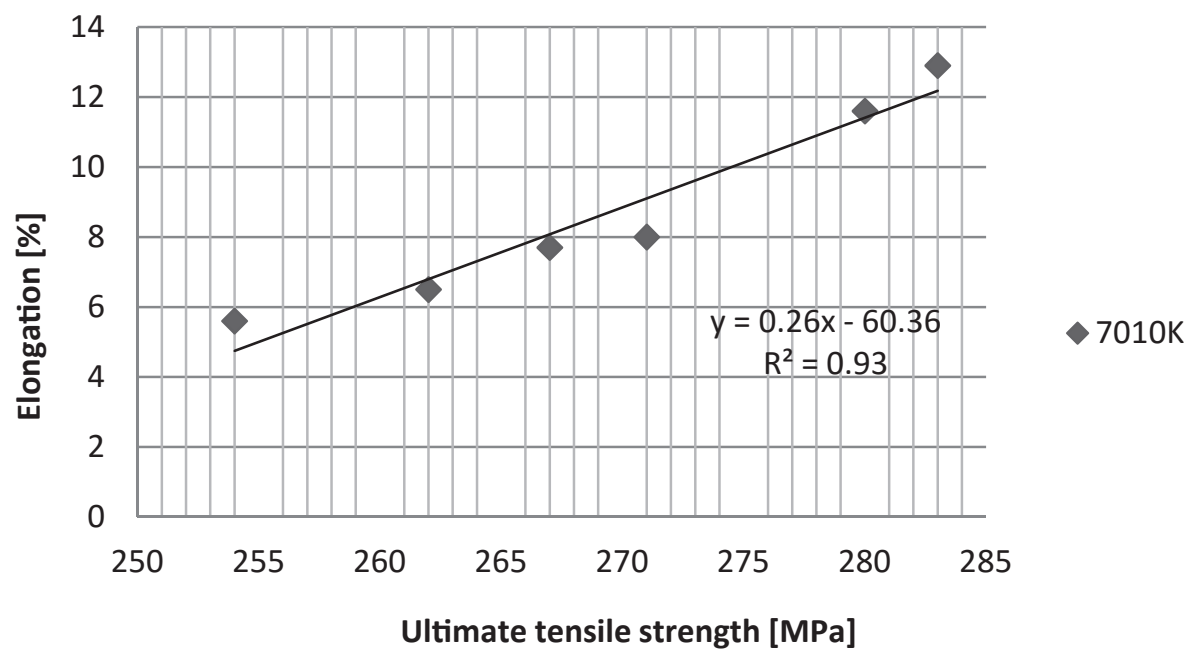

Fig. 7. Linear correlation between elongation and ultimate tensile strength of the sample made of the 7010 alloy 


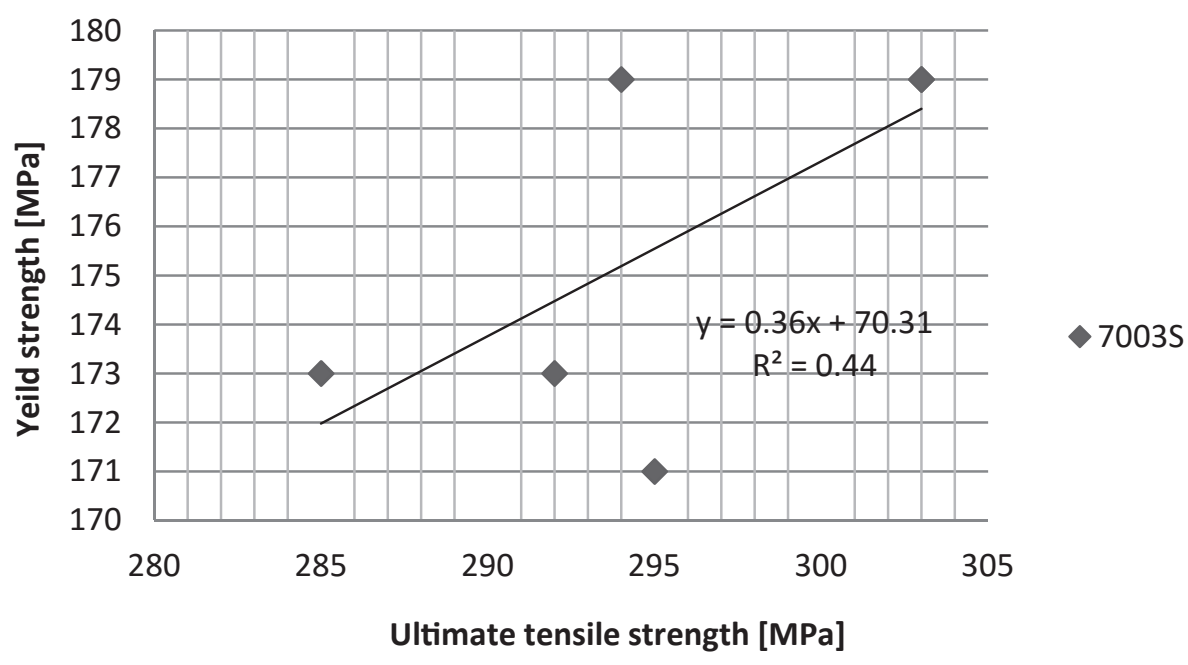

Fig. 8. Linear correlation between yield strength and ultimate tensile strength of the sample made of the 70035 alloy

\section{Conclusions}

Aluminum alloys of the 7xxx series, one of the base material, are meant for metal-working processes. Therefore, plasticity parameters are crucial. Forming processes require high yield strength, elongation, and low hardness. High hardness of the alloy can lead to the wear of molds, which is an exceptionally unfavorable effect.

Numerous phases inside the grains existing in the background of the alpha solution can become a basis for precipitation hardeningin the future. Similarities in the $7003 \mathrm{~S}$ and $7010 \mathrm{~K}$ alloys explain the similar strength test results. Resemblance can be also seen in the materials' macro and microstructure.

Statistical analysis of the relationship between elongation and ultimate tensile strength impliesa clear linear dependency between them. This applies to all three alloys: 7010K, 7003, and 7003S.

The non-homogenized 7010 alloy has almost no elongation and the highest hardness. Changes in these parameters are visible in the homogenization process. This is confirmation that aluminum alloys of the $7 x x x$ series are sensitive to changes in the temperature parameters.

Nowadays, studies are being conducted in order to improve plastic parameters by the application of homogenization with changing characteristics and by selecting supersaturating and aging parameters. 


\section{References}

[1] Lityńska-Dobrzyńska L., Dutkiewicz J., Maziarz W., Góral A.: Microstructure of Rapidly Solidified Al-12Zn3Mg-1.5Cu Alloy with Zr and Sc Additions. Materials Transactions, 52, 3 (2011), 309-314

[2] Kwak Z., Rzadkosz S., Garbacz-Klempka A., Krok W.: Wpływ dodatków stopowych na mikrostrukturę i właściwości stopów serii 7xxx. Archives of Foundry Engineering, 4 (2014), 83-88

[3] Kwak Z., Rzadkosz S., Garbacz-Klempka A., Perek-Nowak M., Krok W.: The properties of 7xxx series alloys formed by alloying additions. Archives of Foundry Engineering, 2 (2015), 59-64

[4] Haider T. Naeem, Kahtan S. Mohammed: Microstructural Evaluation and Mechanical Properties of an Al-Zn-Mg-Cu-Alloy after Addition of Nickel under RRA Conditions. Materials Sciences and Applications, 4 (2013), 704-711

[5] https://www.smithmetal.com/7010.htm [access: 31.05.2016]

[6] http://www.hydro.com/en/Press-room/Feature-stories/Aluminium/High-strength-aluminium-for-automotive-applications/ [access: 31.05 .2016 ]

[7] Reza Eivani A., Zhou J., Duszczyk J.: Microstructural evolution during the homogenization of Al-Zn-Mg aluminium alloys. In: InTech, Chapters published November 21, 2011 under CC BY 3.0 license, 2011, 477-516. Available from: http://www.intechopen.com/books/recenttrends-in-processing-and-degradation-of-aluminium-alloys/microstructural-evolution-during-thehomogenization-of-al-zn-mg-aluminum-alloys [access: 26.03.2016]

[8] Suenger S., Kreissle M., Kahnert M., Zaeh M.F.: Influence of Process Temperature on Hardness of Friction Stir Welded High Strength Aluminum Alloys for Aerospace Applications. Procedia CIRP, 24 (2014), $120-124$

[9] Grandfield J.F., McGlade P.T.: DC casting of aluminium: process behaviour and technology. Materials Forum-Rushcutters Bay, 20 (1996), 29-51

[10] Chemical composition according to standard PN-EN 573-3:2014-02 English version, Aluminium i stopy aluminium - Skład chemiczny i rodzaje wyrobów przerobionych plastycznie [Aluminum and Aluminum Alloys - Chemical composition and the type of products obtained by metal-working processes]

[11] Kwak Z., Garbacz-Klempka A., Perek-Nowak M.: Microstructure of selected 7xxx series aluminum alloys obtained by semi-continuous casting. Prace Instytutu Odlewnictwa, 56, 3 (2016), 221-232 